\title{
Effects of agricultural and urban impacts on macroinvertebrates assemblages in streams (Rio Grande do Sul, Brazil)
}

\author{
Luiz Ubiratan Hepp'; Silvia V. Milesi'; Cristiane Biasi' ${ }^{1} \&$ Rozane M. Restello ${ }^{1}$
}

\author{
${ }^{1}$ Laboratório de Biomonitoramento, Departamento de Ciências Biológicas, Universidade Regional Integrada do Alto Uruguai \\ e das Missões. Avenida Sete de Setembro 1621, Caixa Postal 743, 99700-000 Erechim, Rio Grande do Sul, Brasil. \\ E-mail: Ihepp@uri.com.br; rrozane@uri.com.br
}

\begin{abstract}
This study evaluates the effects of agricultural and urban activities on the structure and composition of benthic communities of streams in the state of Rio Grande do Sul, Brazil. Benthic macroinvertebrates were collected in streams influenced by urbanization and agriculture and in streams with no anthropogenic disturbances (reference streams). Organism density was superior in urban streams when compared with streams in the other two areas. The taxonomic richness and Shannon diversity index were higher in reference streams. The benthic fauna composition was significantly different among land uses. The classification and ordination analyses corroborated the results of variance analyses demonstrating the formation of clusters corresponding to streams with similar land use. Seasonality was also found to influence the benthic community, though in a lesser degree than land use.
\end{abstract}

KEY WORDS. Biomonitoring; environmental quality; land uses.

One of the main causes of degradation in aquatic ecosystems is inadequate land use, which affects the characteristics of drainage basins by modifying the physical and chemical characteristics of water bodies and the composition of the aquatic biota (HepP \& SANTOS 2009). Water characteristics are regulated by both natural and anthropogenic factors (BAHAR et al. 2008). For example, intense urban and agricultural activities increase the input of organic residues, nutrients and metals into rivers and streams (Milesi et al. 2008). Additionally, by removing the riparian vegetation, a very common practice in agricultural areas, anthropogenic activities eliminate a natural protection against erosion, increasing the input of sediments, nutrients and other pollutants (Nessimian et al. 2008) into water bodies.

A common result of urbanization and other anthropic activities in stream ecosystems is a reduction in the number of taxa that are less tolerant to modifications in the water quality, together with an increase in the number of pollution-tolerant taxa (SмiтH \& LAMP 2008), often resulting in the local extinction of native species (Roy et al. 2003).

Biomonitoring is a method used to determine water quality using biological communities. Even though a large number of organisms have been used to monitor the effects of pollutants in aquatic ecosystems, environmental agencies have consistently employed benthic macroinvertebrate communities to monitor water bodies (BACEY \& SPURLOCK 2007).

Studies in different parts of the world show that benthic macroinvertebrates are generally good bioindicators of water quality in streams impacted by urbanization (Roy et al. 2003, Bacey \& Spurlock 2007, Smith \& Lamp 2008), agriculture
(VondraceK et al. 2005), pastures (DolÉDec et al. 2006, Mori \& Brancelj 2006, McIver \& McInnis 2007), ions (Doi et al. 2007, Milesi et al. 2008) and deforestation (Megan et al. 2007). In Brazil, large-scale (landscape) biomonitoring studies using macroinvertebrates have been carried out in the Southeastern region of the country. Some examples are the study of Oметто et al. (2004) in the Piracicaba River basin, Corbi \& TrivinhoStrixino (2006) in the sugarcane region of São Paulo, BAPTISTA et al. (2007) in the region of Atlantic forest and Pompeu et al. (2005) in the basin of the Velhas River, Minas Gerais. In northern Brazil, Nessimian et al. (2008) used macroinvertebrates to evaluate the effect of different land uses (deforested area)

In a study carried out in southern Brazil, Hepp \& SANTOS (2009) evaluated the impact of different land uses on local benthic communities. When streams in conserved areas were compared with streams in urbanized and pasture areas, significant differences in organism density and taxonomic richness were found: in both urban sites and pastures, macroinvertebrate density was higher and species richness was significantly lower than in conserved areas. These results are consistent with those reported by Molozzi et al. (2007), who studied the effects of different management strategies on the rice fields of Santa Catarina. In their data, species richness was significantly lower in areas where the riparian vegetation had been removed and organic matter input was consequently higher.

Knowing the impacts of anthropic activities on water bodies is crucial for their environmental management, an increasingly important activity due to global demand for water resources (Dewson et al. 2007). The main aim of this study was

() 2010 Sociedade Brasileira de Zoologia | www.sbzoologia.org.br | All rights reserved. 
to answer the following question: do different kinds of environmental impact cause different types of alterations in the composition and structure of macroinvertebrate communities? We believe that the answer to this question can provide important information to environmental managers and to the public at large, information that can help in the conservation and recovery of natural resources in the North region of the state of Rio Grande do Sul, Brazil.

\section{MATERIAL AND METHODS}

This study was carried out in Erechim, situated in the northern region of the state of Rio Grande do Sul $\left(27^{\circ} 29^{\prime} 6.13^{\prime \prime}\right.$ and $27^{\circ} 47^{\prime} 0.97^{\prime \prime} \mathrm{S} ; 52^{\circ} 21^{\prime} 3.28^{\prime \prime}$ and $52^{\circ} 8^{\prime} 43.3^{\prime \prime} \mathrm{W}$ ). Stretches from first to third orders in the hydrographic basin were selected, corresponding to the different land uses (Tab. I). The geological formation throughout the basins is basaltic and the typical soil is classified as "Ec" (Erechim Latossol Roxo Distrófico). The density drainage in the various sites (see below) was similar, oscillating from 12.53 to $13.01 \mathrm{~m} \mathrm{ha}^{-1}$ (RAmpazzo et al. 2004). We classified our collecting sites as urban, agricultural, and reference sites, as follows: 1) urban sites consisted of four streams downstream of the urban perimeter. About $90 \%$ of the urban perimeter of Erechim is within this hydrographic basin (sites 1, 2, 3 and 4). The substrate is chiefly composed of rocks and leaves; 2 ) agricultural sites consisted of four sites located within a hydrographic basin where land use ( $>95 \%$ ) is predominantly agricultural (sites 5, 6, 7 and 8); soy (summer) and wheat (winter) are the main crops. The sites are deforested and the substrate is composed of rocks and soil; 3) reference sites, chosen based on their environmental integrity (sites 9, 10, 11 and 12) were characterized as follows: absence of anthropogenic disturbances, presence of native riparian vegetation, variety of habitats on the stream bed, among other aspects. The distribution of the sampling sites is represented in figure 1.

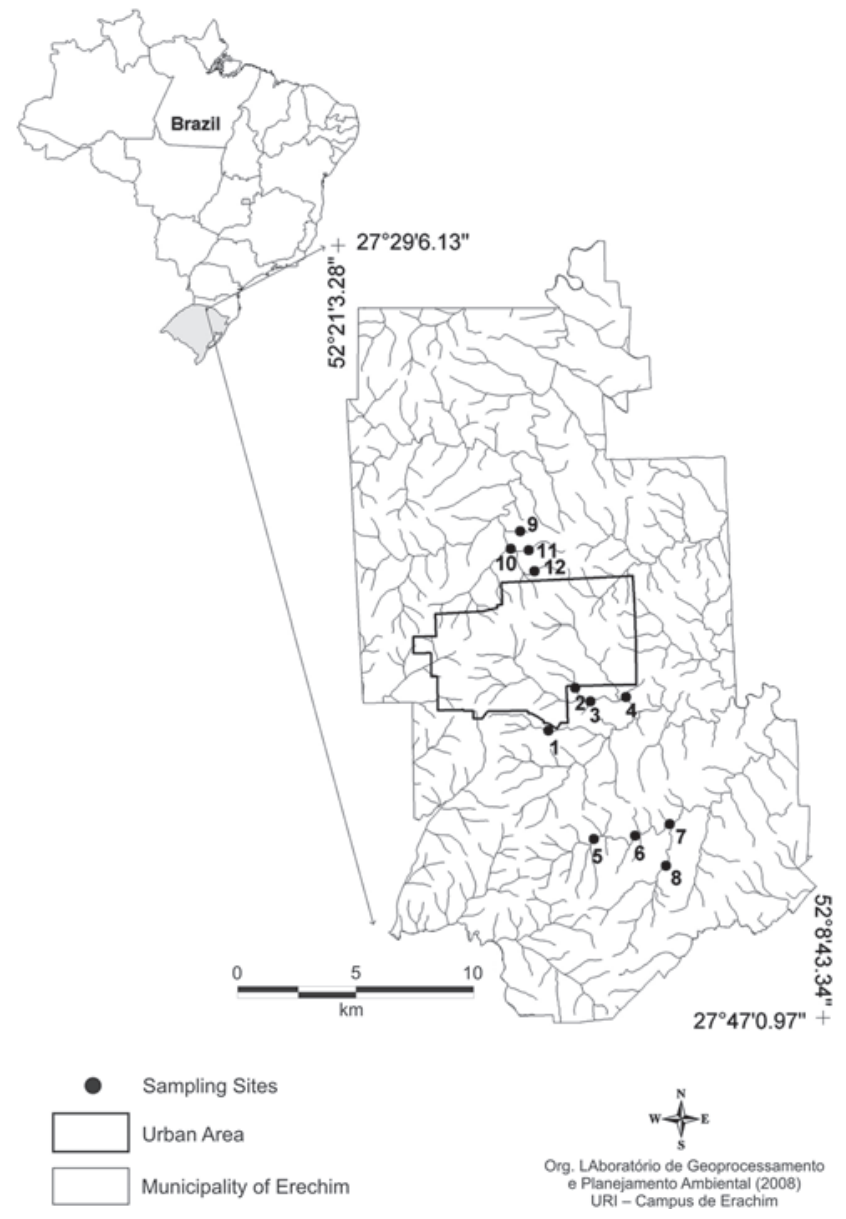

Figure 1. Dsitribution of the sampling sites in the municipality of Erechim.

Table I. Characteristics of the sampling sites in Erechim, Rio Grande do Sul state.

\begin{tabular}{cccccccc}
\hline Sites & Land Use & Geographic Coordinates & Altitud $(\mathrm{m})$ & Order & Width $(\mathrm{m})$ & Deep $(\mathrm{m})$ & Flow $\left(\mathrm{m}^{3} \mathrm{~s}^{-1}\right)$ \\
\hline 1 & Urban & $27^{\circ} 39^{\prime} 21.1^{\prime \prime}, 52^{\circ} 15^{\prime} 0.34^{\prime \prime}$ & 694 & $2 \mathrm{sd}$ & $1.75-0.50$ & $0.12-0.03$ & $0.3-0.9$ \\
2 & Urban & $27^{\circ} 39^{\prime} 58.1^{\prime \prime}, 52^{\circ} 16^{\prime} 35.4^{\prime \prime}$ & 644 & 1 st & $0.95-0.95$ & $0.18-0.28$ & $0.4-0.2$ \\
3 & Urban & $27^{\circ} 39^{\prime} 41.2^{\prime \prime}, 52^{\circ} 14^{\prime} 40.2^{\prime \prime}$ & 620 & 3 th & $6.50-3.50$ & $0.15-0.26$ & $0.7-0.8$ \\
4 & Urban & $27^{\circ} 39^{\prime} 345^{\prime \prime}, 52^{\circ} 13^{\prime} 44.5^{\prime \prime}$ & 695 & 1 st & $6.40-5.90$ & $0.15-0.15$ & $0.9-1.2$ \\
5 & Agriculture & $27^{\circ} 42^{\prime} 50.6^{\prime \prime}, 52^{\circ} 14^{\prime} 37.0^{\prime \prime}$ & 652 & 3 th & $3.28-4.70$ & $0.28-0.13$ & $0.5-0.6$ \\
6 & Agriculture & $27^{\circ} 42^{\prime} 47.4^{\prime \prime}, 52^{\circ} 13^{\prime} 32.7^{\prime \prime}$ & 658 & 2 sd & $2.90-3.18$ & $0.13-0.17$ & $0.7-0.7$ \\
7 & Agriculture & $27^{\circ} 43^{\prime} 29.5^{\prime \prime}, 52^{\circ} 12^{\prime} 45.1^{\prime \prime}$ & 647 & 1 st & $2.57-1.78$ & $0.15-0.15$ & $0.7-0.8$ \\
8 & Agriculture & $27^{\circ} 42^{\prime} 32.1^{\prime \prime}, 52^{\circ} 12^{\prime} 38.9^{\prime \prime}$ & 620 & 3 th & $3.00-3.20$ & $0.19-0.15$ & $0.4-0.5$ \\
9 & Reference area & $27^{\circ} 36^{\prime} 08.6^{\prime \prime}, 52^{\circ} 16^{\prime} 12.4^{\prime \prime}$ & 605 & 1 st & $1.00-0.80$ & $0.11-0.07$ & $0.2-0.4$ \\
10 & Reference area & $27^{\circ} 36^{\prime} 09.2^{\prime \prime}, 52^{\circ} 16^{\prime} 12.8^{\prime \prime}$ & 601 & 2 sd & $1.20-1.35$ & $0.07-0.10$ & $0.5-0.3$ \\
11 & Reference area & $27^{\circ} 35^{\prime} 41.4^{\prime \prime}, 52^{\circ} 16^{\prime} 49.1^{\prime \prime}$ & 564 & 1 st & $0.85-1.67$ & $0.03-0.05$ & $0.1-0.4$ \\
12 & Reference area & $27^{\circ} 36^{\prime} 34.3^{\prime \prime}, 52^{\circ} 16^{\prime} 07.0^{\prime \prime}$ & 610 & $2 s d$ & $1.32-1.55$ & $0.03-0.04$ & $0.1-0.6$ \\
\hline
\end{tabular}


For characterization of the sites, analysis in triplicate of the following environmental variables was carried out in all streams sampled: current velocity (fluxometer), water temperature and dissolved oxygen (in situ, oximeter), $\mathrm{pH}$ (in situ, potenciometric method), electric conductivity (in situ, potenciometric method), turbidity (nephelometric method), ammonia and total phosphorus (espectrofotometric method). The methodology used to gather this data is described in Standard Methods (APHA 1998).

The benthic organisms were sampled in different substrates (leaves, stones and sand) with a Surber sampler (mesh = $225 \mu \mathrm{m}$; area $=0.1 \mathrm{~m}^{2}$ ) within a $10 \mathrm{~m}$ ratio of the chosen site. The biological samples were fixed in the field with 5\% formalin and taken to the laboratory for selection and identification. Identification was carried out to the lowest possible taxonomic level based on the available literature (Fernandez \& Domingues 2001, Merritt \& Cummins 1996). However, according to Melo (2005) and Corbi \& Trivinho-STrixino (2006), familylevel identifications of benthic macroinvertebrates for biomonitoring purposes do not compromise the results.

Density (organisms.m-2) and taxonomic richness (represented by the number of macroinvertebrate taxa identified) were calculated for each site. Next, rarefaction curves for the estimation of macroinvertebrate taxonomic richness were constructed. The rarefaction was calculated based on the lowest values of organism density obtained in each stream (Gotelli \& Cowell 2001). The standard sample size used for comparison, when calculating rarefaction, was 100 organisms. This value, which corresponds to the lower density registered in our data (smallest sample size), was obtained in summer, for site 4 . The Shannon Diversity index and Pielou Evenness were also calculated (MAgurran 2004). To evaluate the differences among the density, rarefied richness, Shannon Diversity index and evenness in streams, an Analysis of Variance was used (ANOVA; Gotelli \& ELLISON 2004). To compare the benthic community composition among the different sites, collecting periods, and collecting dates, a Multivariate Analysis of Variance (MANOVA) was applied to the density $\log (\mathrm{x}+1)$ transformed. With the density previously $(\log [\mathrm{x}+1])$ transformed, a classification analysis was carried out using UPGMA method with the BrayCurtis coefficient of dissimilarity. The analyses were carried out using the "vegan" package (OKSANEN et al. 2008) of statistical programs R (R Development Core Team 2008) and Multiv Beta version 2.5 (PILlar 2001).

\section{RESULTS}

Organism density did not differ among the streams in the winter period. In summer, the urban streams showed the highest densities of organisms (ANOVA, $\mathrm{F}_{2,9}=5.23, \mathrm{p}=0.03$ ). According to the Tukey test, the differences occurred between the reference and urban streams ( $S S=4.46, \mathrm{p}<0.05$, Figs 2-5). Streams in reference areas presented higher rarefied richness in winter (ANOVA, $\mathrm{F}_{2,9}=8.88, \mathrm{p}=0.007$, Figs 2-5) and summer (ANOVA, $\mathrm{F}_{2,9}=13.8, \mathrm{p}=0.002$, Figs 2-5). In winter, differences
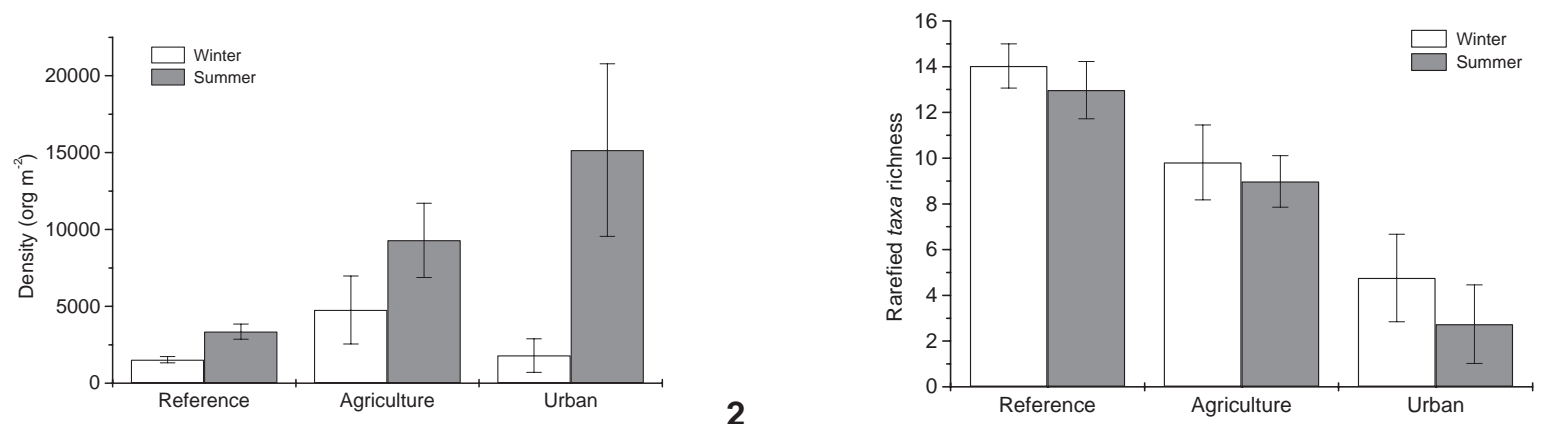

2
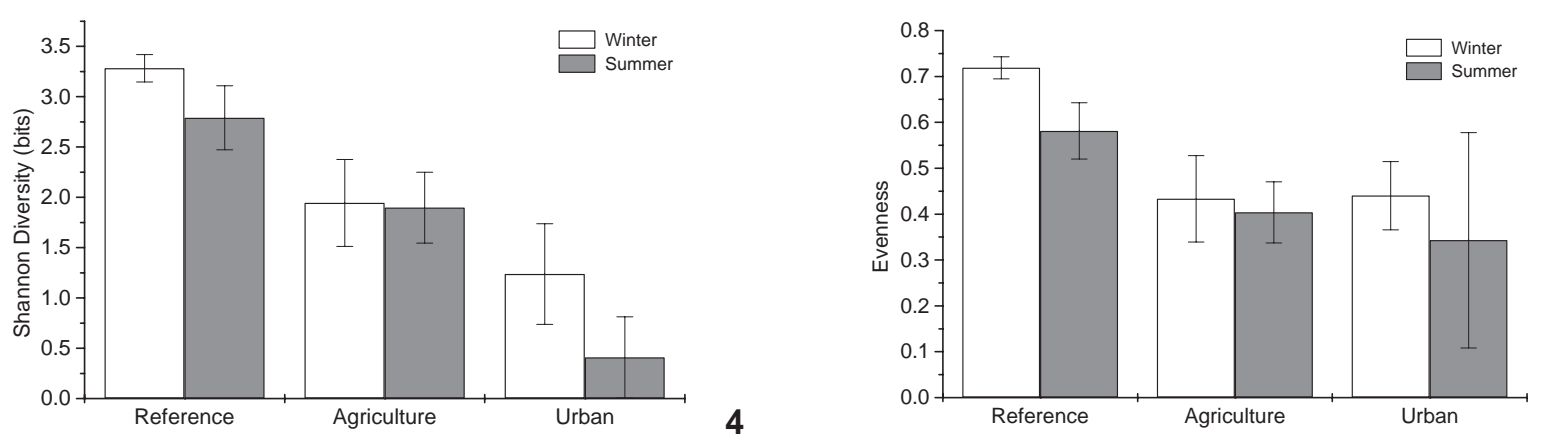

Figures 2-5. Average values and standard error ( \pm Standard Error) of density (2), richness (3), Shannon Diversity index (4) and Evenness (5) of benthic macroinvertebrates collected in streams with different land uses in Erechim. 
occurred between reference and urban areas (Tukey test, SS = 5.95, $\mathrm{p}<0.01)$. In summer, differences were observed between reference and urban areas (Tukey test, $\mathrm{SS}=7.37, \mathrm{p}<0.01$ ) and between agricultural and urban areas (Tukey test, $\mathrm{SS}=4.49, \mathrm{p}<$ 0.05). The Shannon diversity index differed among the varied land uses in both seasons (ANOVA, $\mathrm{F}_{2,9}=7.10, \mathrm{p}=0.01$ and $\mathrm{F}_{2,9}$ $=11.21, \mathrm{p}=0.004$, winter and summer, respectively). In winter, the differences occurred between reference and urban areas (Tukey test, $\mathrm{SS}=5.24, \mathrm{p}<0.05$ ). In summer, differences occurred between reference and urban areas (Tukey test, SS = 6.62, $\mathrm{p}<0.01$ ) and agricultural and urban areas (Tukey test, SS $=4.14, \mathrm{p}<0.05)$. The evenness showed differences among the land uses in winter (ANOVA, $\mathrm{F}_{2,9}=5.32, \mathrm{p}=0.02$ ) and summer (ANOVA, $\mathrm{F}_{2,9}=11.23, \mathrm{p}=0.004$ ). The Tukey test demonstrated that in winter the differences occurred between reference and urban areas ( $\mathrm{SS}=4.04, \mathrm{p}<0.05$ ). In summer, the differences were between reference and urban areas ( $S S=6.62, \mathrm{p}<0.01$ ) and between agricultural and urban areas ( $S S=4.21, \mathrm{p}<0.05)$.

In this study, a total of 58 taxa were identified among the Acarina, Crustacea, Mollusca, Annelida and Insecta. In urban streams, the dominance of Chironomidae (Diptera) and Oligochaeta species was evident, accounting for more than $70 \%$ of the fauna collected in these streams. The composition of the benthic community showed significant differences among the different land uses in winter (MANOVA, SS $=92.37, \mathrm{p}=0.001$, Tab. III) and summer (MANOVA, SS $=121.02, \mathrm{p}=0.002$, Tab. III). According to "a posteriori" analyses carried out among the three land uses in winter, significant differences were observed (reference $\mathrm{x}$ urban areas: $S S=47.7, p=0.03$; reference $x$ agriculture areas: $S S$ $=36.5, p=0.02$, agriculture $x$ urban areas: $S S=54.3, p=0.02)$. In summer, differences were significant between reference e urban areas (SS $=69.6, \mathrm{p}=0.03$ ) and reference and agricultural areas (SS $=37.3, \mathrm{p}=0.02$ ). However, urban and agricultural areas did not differ in summer with respect to community composition.

The Cluster analysis revealed groups characterized by land use: a group formed by streams located in reference areas; a second group formed by a mixture of streams in reference and agricultural areas; a third group with predominance of agricultural streams; and a fourth group formed by urban streams (Fig. 6).

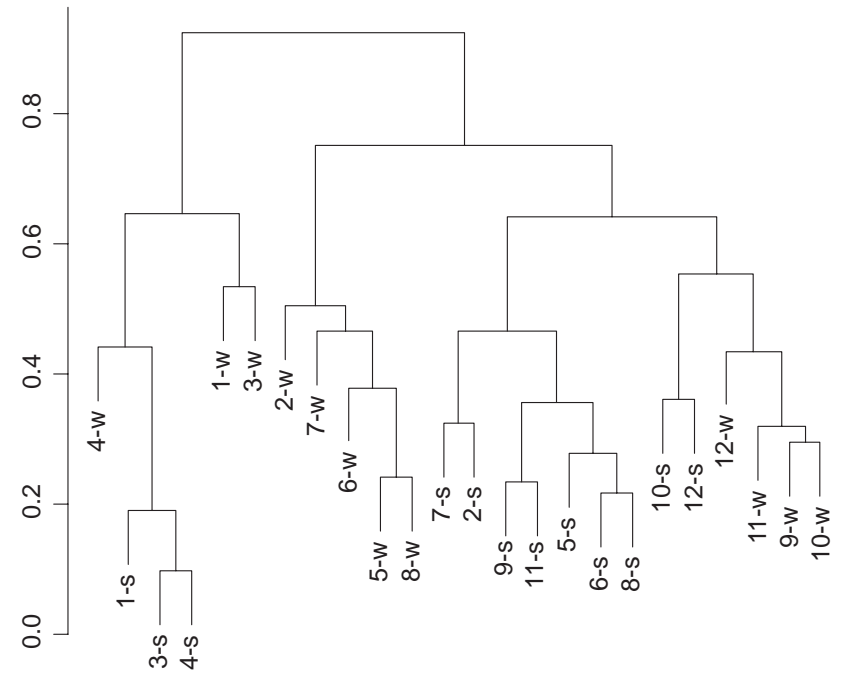

Figure 6. Dendrogram of grouping (UPGMA, Bray-Curtis) in streams with different land uses influence in Erechim. Numbers = sites, $\mathrm{w}=$ winter, $\mathrm{s}=$ summer. Urban Sites: numbers 1, 2, 3, and 4; Agriculture Sites: numbers 5, 6, 7, and 8; Reference Sites: numbers 9, 10,11 , and 12.

\section{DISCUSSION}

The higher values obtained for nutrients and the lower amounts of dissolved oxygen in urban streams were most likely a consequence of the input of organic materials in the water. Additionally, pollution sources such as sewer discharge and industrial residues seem to have been responsible for the high concentrations of ammonia and total phosphorus. SAlomoni et al. (2007), in a study carried out in the Gravataí River (Rio Grande do Sul), pointed out that changes in that river were a consequence of the increased concentration of nutrients discharged in the water column. The contaminants, mainly organic nutrients that are launched in urbanized streams, cause alterations in the physical-chemical characteristics of the water (BAHAR et al. 2008).

Table II. Average values and standard deviation of the environmental variables measured in streams (Erechim, Rio Grande do Sul, Brazil).

\begin{tabular}{|c|c|c|c|c|c|c|}
\hline \multirow{2}{*}{ Variables } & \multicolumn{2}{|c|}{ Reference Streams } & \multicolumn{2}{|c|}{ Agriculture Streams } & \multicolumn{2}{|c|}{ Urban Streams } \\
\hline & Winter & Summer & Winter & Summer & Winter & Summer \\
\hline Water Temperature $\left({ }^{\circ} \mathrm{C}\right)$ & $14.65 \pm 0.63$ & $19.37 \pm 0.65$ & $15.90 \pm 2.00$ & $26.25 \pm 1.61$ & $17.70 \pm 1.84$ & $24.50 \pm 2.11$ \\
\hline $\mathrm{pH}$ & $7.21 \pm 0.29$ & $6.91 \pm 0.17$ & $6.72 \pm 0.47$ & $6.68 \pm 0.31$ & $6.52 \pm 0.49$ & $6.62 \pm 0.13$ \\
\hline Dissolved Oxigen $\left(\mathrm{mg} \mathrm{l}^{-1}\right)$ & $8.69 \pm 0.04$ & $7.79 \pm 0.21$ & $8.12 \pm 0.41$ & $7.81 \pm 0.36$ & $21.67 \pm 17.76$ & $5.00 \pm 2.15$ \\
\hline Electric Conductivity $\left(\mu \mathrm{S} \mathrm{cm}^{-1}\right)$ & $59.17 \pm 11.48$ & $59.25 \pm 3.88$ & $52.30 \pm 16.83$ & $6.68 \pm 0.31$ & $6.25 \pm 1.77$ & $10.84 \pm 3.32$ \\
\hline Turbitidy (NTU) & $5.06 \pm 2.67$ & $6.17 \pm 1.70$ & $8.12 \pm 0.41$ & $7.80 \pm 0.36$ & $192.18 \pm 120.30$ & $128.25 \pm 75.19$ \\
\hline Ammonia $\left(\mathrm{mg} \mathrm{l}^{-1}\right)$ & $0.057 \pm 0.014$ & $0.020 \pm 0.008$ & $0.059 \pm 0.021$ & $0.027 \pm 0.003$ & $0.841 \pm 0.551$ & $0.610 \pm 0.388$ \\
\hline Total Phosphorus (mg l-1) & $0.068 \pm 0.013$ & $0.106 \pm 0.002$ & $0.085 \pm 0.012$ & $0.180 \pm 0.099$ & $0.350 \pm 0.135$ & $0.473 \pm 0.119$ \\
\hline
\end{tabular}


Table III. Values of organisms density in streams with different land uses influence in Erechim, Rio Grande do Sul state. ( $\boldsymbol{\square})<10,(\bullet)$ 11-50, (스) 51-100, $(\diamond)>100$.

\begin{tabular}{|c|c|c|c|c|c|c|}
\hline \multirow{2}{*}{ Taxa } & \multicolumn{2}{|c|}{ Reference streams } & \multicolumn{2}{|c|}{ Agriculture streams } & \multicolumn{2}{|c|}{ Urban streams } \\
\hline & Winter & Summer & Winter & Summer & Winter & Summer \\
\hline \multicolumn{7}{|l|}{ Platyhelminthes } \\
\hline Turbellaria & $\Delta$ & $\diamond$ & $\Delta$ & $\diamond$ & $\mathbf{\square}$ & $\mathbf{\square}$ \\
\hline \multicolumn{7}{|l|}{ Annelida } \\
\hline Hyrudinea & $\bullet$ & $\bullet$ & $\Delta$ & $\boldsymbol{\square}$ & $\bullet$ & $\mathbf{\square}$ \\
\hline Oligochaeta & $\bullet$ & $\Delta$ & $\Delta$ & $\Delta$ & $\diamond$ & $\diamond$ \\
\hline \multicolumn{7}{|l|}{ Mollusca } \\
\hline Bivalvia & $\boldsymbol{\Delta}$ & $\Delta$ & $\bullet$ & & $\diamond$ & \\
\hline Gastropoda & $\diamond$ & $\diamond$ & $\bullet$ & $\bullet$ & $\Delta$ & $\boldsymbol{\Delta}$ \\
\hline \multicolumn{7}{|l|}{ Arachnida } \\
\hline Acari & & - & - & - & & \\
\hline \multicolumn{7}{|l|}{ Crustacea } \\
\hline Aeglidae & घ & $\bullet$ & $\mathbf{\square}$ & & $\mathbf{\square}$ & $\mathbf{\square}$ \\
\hline Copepoda & & & $\mathbf{\square}$ & $\mathbf{\square}$ & & \\
\hline Hyalella & $\bullet$ & $\diamond$ & $\mathbf{\square}$ & & & \\
\hline \multicolumn{7}{|l|}{ Insecta } \\
\hline \multicolumn{7}{|l|}{ Collembola } \\
\hline Isotomidae & & & $\diamond$ & $\bullet$ & & $\mathbf{\square}$ \\
\hline Poduridae & & $\mathbf{\square}$ & $\diamond$ & $\mathbf{a}$ & & \\
\hline Sminthuridae & & & $\bullet$ & & & \\
\hline Hypogastruridae & & & & & $\bullet$ & \\
\hline \multicolumn{7}{|l|}{ Ephemeroptera } \\
\hline Baetidae & $\diamond$ & $\mathbf{\square}$ & $\diamond$ & $\diamond$ & $\Delta$ & $\Delta$ \\
\hline Caenidae & - & $\diamond$ & - & $\diamond$ & & - \\
\hline Leptohyphidae & $\diamond$ & $\diamond$ & $\diamond$ & $\diamond$ & & \\
\hline Leptophlebiidae & $\diamond$ & $\diamond$ & $\Delta$ & $\diamond$ & $\mathbf{\square}$ & $\mathbf{\square}$ \\
\hline \multicolumn{7}{|l|}{ Odonata } \\
\hline Calopterygidae & घ & [ & & - & & [ \\
\hline Coenagrionidae & $\mathbf{\square}$ & & $\mathbf{\square}$ & $\bullet$ & & \\
\hline Lestidae & & & & $\mathbf{\square}$ & & \\
\hline Corduliidae & $\mathbf{\square}$ & $\mathbf{\square}$ & & & $\mathbf{\square}$ & \\
\hline Gomphidae & & $\mathbf{\square}$ & & & & - \\
\hline Libellulidae & - & & $\mathbf{\square}$ & & & \\
\hline \multicolumn{7}{|l|}{ Plecoptera } \\
\hline Gripopterygidae & $\diamond$ & $\mathbf{\square}$ & $\bullet$ & $\mathbf{\square}$ & & \\
\hline Perlidae & $\diamond$ & & - & - & & \\
\hline \multicolumn{7}{|l|}{ Hemiptera } \\
\hline Belostomatidae & & & & $\mathbf{\square}$ & & \\
\hline Corixidae & & $\Delta$ & & $\diamond$ & & \\
\hline \multicolumn{7}{|l|}{ Naucoridae } \\
\hline Veliidae & - & & & & & \\
\hline
\end{tabular}


Table III. Continued.

\begin{tabular}{|c|c|c|c|c|c|c|}
\hline \multirow{2}{*}{ Taxa } & \multicolumn{2}{|c|}{ Reference streams } & \multicolumn{2}{|c|}{ Agriculture streams } & \multicolumn{2}{|c|}{ Urban streams } \\
\hline & Winter & Summer & Winter & Summer & Winter & Summer \\
\hline \multicolumn{7}{|l|}{ Megaloptera } \\
\hline Corydalidae & $\mathbf{\square}$ & & $\mathbf{\square}$ & $\bullet$ & & $\mathbf{\square}$ \\
\hline \multicolumn{7}{|l|}{ Coleoptera } \\
\hline Elmidae & $\diamond$ & $\diamond$ & $\diamond$ & $\diamond$ & $\Delta$ & $\Delta$ \\
\hline Hydrophilidae & $\Delta$ & $\diamond$ & $\mathbf{\square}$ & & & \\
\hline Psephenidae & $\Delta$ & $\diamond$ & $\mathbf{\square}$ & $\bullet$ & & \\
\hline \multicolumn{7}{|l|}{ Diptera } \\
\hline Blephariceridae & & $\bullet$ & & & & \\
\hline Ceratopogonidae & $\bullet$ & $\boldsymbol{\Delta}$ & $\bullet$ & $\bullet$ & $\mathbf{\square}$ & $\mathbf{\square}$ \\
\hline Chironomidae & $\diamond$ & $\diamond$ & $\diamond$ & $\diamond$ & $\diamond$ & $\diamond$ \\
\hline Culicidae & $\mathbf{\square}$ & $\boldsymbol{\Delta}$ & & & & \\
\hline Dixidae & & $\mathbf{\square}$ & & & & \\
\hline Dolichopodidae & $\mathbf{\square}$ & $\mathbf{\square}$ & & & $\mathbf{\square}$ & \\
\hline Empididae & $\mathbf{\square}$ & & $\mathbf{\square}$ & & & $\mathbf{\square}$ \\
\hline Muscidae & & $\bullet$ & & $\bullet$ & & \\
\hline Psychodidae & $\mathbf{\square}$ & & $\bullet$ & & $\mathbf{\square}$ & $\mathbf{\square}$ \\
\hline Sciomyzidae & $\mathbf{\square}$ & $\bullet$ & & $\bullet$ & & \\
\hline Simuliidae & $\diamond$ & & $\diamond$ & & $\Delta$ & \\
\hline Stratiomyidae & $\mathbf{\square}$ & $\diamond$ & & $\diamond$ & $\bullet$ & $\diamond$ \\
\hline Tipulidae & $\bullet$ & $\mathbf{\square}$ & $\bullet$ & & & \\
\hline Lepidoptera & $\mathbf{\square}$ & $\Delta$ & $\Delta$ & $\mathbf{\square}$ & & \\
\hline \multicolumn{7}{|l|}{ Trichoptera } \\
\hline Calamoceratidae & $\diamond$ & $\diamond$ & $\mathbf{\square}$ & $\bullet$ & $\mathbf{\square}$ & \\
\hline Glossosomatidae & $\boldsymbol{\square}$ & $\Delta$ & $\Delta$ & $\bullet$ & & $\mathbf{\square}$ \\
\hline Helicopsychidae & $\mathbf{\square}$ & $\Delta$ & & $\diamond$ & & $\mathbf{\square}$ \\
\hline Hydrobiosidae & & $\boldsymbol{\square}$ & & $\diamond$ & & $\Delta$ \\
\hline Hydropsychidae & $\diamond$ & $\bullet$ & $\diamond$ & $\bullet$ & $\diamond$ & $\bullet$ \\
\hline Hydroptilidae & $\boldsymbol{\square}$ & $\bullet$ & $\Delta$ & & $\mathbf{\square}$ & \\
\hline Leptoceridae & & $\diamond$ & & $\diamond$ & & $\diamond$ \\
\hline Odontoceridae & $\mathbf{\square}$ & & $\mathbf{\square}$ & & & \\
\hline Philopotamidae & $\mathbf{\square}$ & $\bullet$ & $\bullet$ & $\mathbf{\square}$ & $\mathbf{\square}$ & $\mathbf{\square}$ \\
\hline Sericostomatidae & $\boldsymbol{\square}$ & $\bullet$ & & $\diamond$ & & $\mathbf{\square}$ \\
\hline
\end{tabular}

A significant effect on the structure and composition of the benthic macroinvertebrate fauna was observed among the different land uses in this study. The streams located in reference areas with native riparian vegetation, higher diversity of habitats and trophic resources, showed greater taxonomic richness (reflected by the Shannon Diversity index) and lower density of organisms. By contrast, a decreased taxonomic richness and a correspondingly lower Shannon Diversity index were observed in urban areas (HерP \& SANTOS 2009). In agricultural streams, however, intermediate patterns were observed. NIYogI et al. (2007) mentioned that the density of macroinvertebrates significantly increases in places with higher nutrient concentrations and fine sediments. Streams under urban influence receive considerable amounts of organic residues (Roy et al. 
2003), whereas agricultural streams receive the input of sediments derived from erosion (Lenat \& CRawford 1994). Erosion and the consequent input of sediments can be observed in the streams studied and may have contributed to an incremental increase in organism densities.

Reference and urban sites differed in average values for all variables measured in all seasons, except for density in winter. The agricultural and urban areas showed differences in richness, Shannon diversity index and evenness only in summer. SMITH \& LAMP (2008) studied the benthic community structure in agricultural and urban areas in Montgomery Co. (USA) streams and observed results similar to ours. According to LENAT \& CRAWFORD (1994), pollution intolerant organisms are frequent and abundant in regions with a higher availability of habitats.

The fauna composition was different among the land uses, a result consistent with the findings of OмЕтто et al. (2004), who demonstrated that urban streams have lower concentrations of dissolved oxygen and higher concentrations of ammonia, affecting the distribution and occurrence of Ephemeroptera, Plecoptera and Trichoptera (EPT orders). Several studies have highlighted the role of the EPT orders as bioindicators (Lenat \& CRAWFord 1994, Doledéc et al. 2006, BaceY \& Spurlock 2007, Molozzi et al. 2007, Hepp \& Santos 2009), because these organisms tend to decrease in numbers or even disappear in regions where sources of (urban) pollution are introduced.

The Cluster analysis showed a pattern of grouping consistent with our expectations. According to SMITH \& LAMP (2008), community structure and composition are more strongly influenced by land use than by season. The similar benthic composition of reference and agricultural streams was likely a result of the EPT richness. The urban areas formed a distinct group because of the physical-chemical characteristics of their streams. The clustering of an urban site with a group predominantly composed of agricultural sites can be an indication of a mixed anthropic disturbance. That urban stream is located in an area within the urban perimeter that releases a lower amount of domestic residues, when compared with the remaining urban regions in our data.

The results of this study show a strong influence of pointpollution sources (urban) and a trend of influence by non-point sources (agriculture) on the benthic community. These results demonstrate that urban and agriculture impacts affect the water quality and aquatic diversity. Management activities are necessary for the recuperation and maintenance of the environmental quality in the study region. Our results can contribute to the generation of integrated information about environmental quality. Traditional evaluation measures based on physical, chemical and bacteriological methods are less efficient in the detection of environmental problems of hydrographic basins. The utilization of bioindicators makes it possible to generate a more integrated evaluation of aquatic ecosystems.

\section{ACKOWLEDGEMENTS}

We thank the Universidade Regional Integrada do Alto Uruguai e das Missões - Campus de Erechim for the Scientific Initiation Scholarship to S.V. MiLESI and C. BIASI and the Secretaria de Ciência e Tecnologia of Rio Grande do Sul State for the financial support.

\section{LITERATURE CITED}

APHA. 1998. Standard methods for the examination of water and wastewater. Washington, D.C., American Public Health Association, $20^{\text {th }}$ ed.,1180p.

BACEY, J. \& F. SPURLOCK. 2007. Biological assessment of urban and agricultural streams in the California Central Valley. Environmental Monitoring Assessment 130 (1-3): 483-493.

Bahar, M.M.; H. Ohmori \& M. Yamamuro. 2008. Relatioship between river water quality and land use in a small river basin running through the urbanizing area of Central Japan. Limnology 9: 19-26.

Baptista, D.F.; D.F. Buss; M. Egler; A. Giovanelli; M.P. Silveira \& J.L. Nessimian. 2007. A multimetric index based on benthic macroinvertebrates for evaluation of Atlantic Forest streams at Rio de Janeiro State, Brazil. Hydrobiologia 575: 83-94.

Corbi, J.J. \& S. Trivinho-Strixino. 2006. Influence of taxonomic resolution of stream macroinvertebrate communities on the evaluation of different land uses. Acta Limnologica Brasiliensia 18: 469-475.

Dewson, Z.S.; A.B.W. James \& R.G. Death. 2007. Invertebrate community responses to experimentally reduced discharge in small streams of different water quality. Journal of the North American Society 26 (4): 754-766.

DoI, H.; A. TAKAGI \& E. KiKUCHI. 2007. Stream macroinvertebrates community affected by point-source metal pollution. International Review Hydrobiology 92 (3): 258-266.

Dolédec, S.; N. Phillips; M. Scarsbrook; R.H. Riley \& C.R. Towsend. 2006. Comparison of structural and functional approaches to determining landuse effects on grassland stream invertebrate communities. Journal of the North American Society 25 (1): 44-60.

Fernandes, H.R. \& E. Domingues. 2001. Guia para determinación de los artropodos bentônicos Sudamericanos. Tucumán, Universidad Nacional de Tucumán, 282p.

Gotelli, N.L. \& R.K. Cowell. 2001. Quantifying biodiversity: procedures and pitfalls in the measurement and comparison of the species richness. Ecology Letters 4: 379-391.

Gotelli, N.J. \& A.M. Elisson. 2004. A primer of ecological statistics. Massachussets, Sinauer Assoc., 510p.

Hagen, E.M.; J.R. Webster \& E.F. Benfield. 2006. Are leaf breakdown rates a useful measure of stream integrity along an agricultural landuse gradient? The Journal North American Benthological Society 25 (2): 330-343.

Hepp, L.U. \& S. Santos. 2009. Benthic communities of streams related to differente land uses in a hydrographic basin in 
southern Brazil. Environmental Monitoring and Assessment 157: 305-318. [doi 10.1007/s10661-008-0536-7].

Lenat, D.R. \& J.K. CrawFord. 1994. Effects of land use on water quality and aquatic biota of three North Carolina piedmont streams. Hydrobiologia 294: 185-199.

MagurRan, A.E. 2004. Measuring Biological Diversity.Malden, Blackwell, 256p.

McIver, J.D. \& M.L. McInnis. 2007. Cattle grazing effects on macroinvertebrates in an Oregon Mountain stream. Rangeland Ecology \& Management 60 (3): 293-303.

Megan, M.H.; M.S. Nash; A.C. Neale \& A.M. Pitchford. 2007. Biological integrity in mid-Atlantic coastal plains headwater streams. Environmental Monitoring and Assessment 124: 141-156.

Melo, A.S. 2005. Effects of taxonomic and numeric resolution on the ability to detect ecological patterns at a local scale using stream macroinvertebrates. Archiv für Hydrobiologie 164 (3): 309-323.

Merritt, R.W. \& K.W. Cummins. 1996. An introduction to the aquatic insects of North America. Iowa, Kendall/Hunt Publishing, $3^{\text {rd }}$ ed., 862p.

Milesi, S.V.; C. Biasi; R.M. Restello \& L.U. Hepr. 2008. Efeito de metais Cobre $(\mathrm{Cu})$ e Zinco $(\mathrm{Zn})$ sobre a comunidade de macroinvertebrados bentônicos em riachos do sul do Brasil. Acta Scientiarum - Biological Science 30 (3): 283289.

Molozzi, J.; L.U. Hepp \& A.S. DiAs. 2007. Influência da cultura de arroz sobre a comunidade bentônica no vale do Itajaí (Santa Catarina, Brasil). Acta Limnologica Brasilensia 19 (4): 383392.

Mori, N. \& A. BrancelJ. 2006. Macroinvertebrates communities of karst springs of two rivers catchments in the Southern Limestone Alps (the Julian Alps, NW Slovenia). Aquatic Ecology 40: 69-83.

Nessimian, J.L.; E.M. Venticinque; J. Zuanon; P. Marco-Jr; M. Gordo; L. Fidelis; J.D. BATISTA; L. Juen. 2008. Land use, habitat integrity, and aquatic insect assemblages in Central Amazonian streams. Hydrobiologia 614 (1): 117-131. [doi 10.1007/s10750-0089441-x].

Niyogi, D.K.; M. Koren; C.J. Arbuckle \& C.R. Townsend. 2007. Stream communities along a catchment land-use gradient: subsidy-stress responses to pastoral development. Environmental Management 39: 213-225.

Oksanen, J.; R. Kindt; P. Legendre; R.B. O’Hara; G.L. Simpson \& M.H.H. Stevens. 2008. Vegan: community ecology package. R package version 1.13-0. Available online at: http://vegan.rforge.r-project.org [Accessed: 20/XII/2008]

OmetTo, J.P.; A. Gessner; L.A. Martinelli \& M.C. Bernardes. 2004. Macroinvertebrate community as indicator of land-use changes in tropical watersheds, southern Brazil. Ecohydrology \& Hydrobiology 4: 37-49.

PILLAR, V.P. 2001. Aplicativo MULTIV (multivariate exploratory analysis, randomization testing and bootstrap resampling) versão 2.4.2. Porto Alegre, Universidade Federal do Rio Grande do Sul, 42p. Available online at: http://ecoqua.ecologia. ufrgs.br./ecoqua/main.html [Accessed: 10/XII/2008].

Pompeu, P.S.; M. Callisto \& C.B.M. Alves. 2005. The effects of urbanization on biodiversity and water quality in the Rio das Velhas basin, Brazil. American Fisheries Society Symposium 47: 11-22.

R Development Core Team. 2008. R: A language and environment for statistical computing. Vienna, R Foundation for Statistical Computing, ISBN 3-900051-07-0.

Rampazzo, S.E.; J.E. Santos; J.R.S. Pires; A.F. Marques. Zoneamento ambiental conceitual para o município de Erechim (RS), p. 351-381. In: J.E. Santos; Cavalheiro, F; Pires, J.S.; C. Henke \& A.M. PIRes (Org.) Faces da policemia da Paisagem: ecologia, planejamento e percepção. São Carlos, Rima, 420p.

Roy, A.H.; M.J. Rosemond; M.J. Paul \& J.B. Wallace. 2003. Stream macroinvertebrate response to catchment urbanization (Georgia, USA). Freshwater Biology 48: 329-346.

SALOMONI, S.E.; O. RochA \& E.H. Leite. 2007. Limnological characterization of Gravataí river, Rio Grande do Sul. Acta Limnologica Brasiliensia 19 (1): 1-14.

SMith, R.F. \& W.O. LAMP. 2008. Comparison of insect communities between adjacent headwater and main-stem streams in urban and rural watersheds.Journal of North American Benthological Society 27 (1): 161-175.

Vondracek, B.; K.L. Blann; C.B. Cox; J.F. Nerbonne; K.G. Mumford \& B.A. Nerbonne. 2005. Land use, spatial scale, and stream systems: lessons from na agriculture region. Environmental Manangement 36: 775-791.

Submitted: 06.II.2009; Accepted: 26.I.2010.

Editorial responsibility: Neusa Hamada 